„Studia Wyborcze”, tom 24, 2017

DOI: $10.26485 / S W / 2017 / 24 / 3$

Zdzisław Ilski*

\title{
WZÓR SYSTEMU WYBORCZEGO POLSKI PRZEDROZBIOROWEJ (XV-XVIII WIEK)
}

\section{WPROWADZENIE}

Państwo polskie weszło na drogę parlamentaryzmu wcześnie, zasadniczo już w XV wieku. Tworząc sejm z wybieralną izbą poselską, aż do epoki rozbiorowej nie opracowano jednolitego aktu prawnego, regulującego procedurę jej powoływania. Nie było ordynacji wyborczej w dzisiejszym rozumieniu. Zbliżone do tego rozstrzygnięcia zapadły dopiero w ostatnich latach istnienia I Rzeczypospolitej.

Mimo to można twierdzić, że państwowość polska miała system wyłaniania posłów na sejm. Główne elementy tego systemu istniały od początku działania sejmu, ale też rozwijały i zmieniały się w czasie. Celem autora jest wskazanie zasadniczych ogniw tegoż systemu, zwrócenie uwagi na tendencje jego rozwoju, poszukiwanie odpowiedzi na pytanie, jaki wzór one wytworzyły i jak został on spożytkowany w tworzeniu jednolitego systemu wyborczego u kresu Rzeczypospolitej.

Problem systemu wyborczego Polski przedrozbiorowej nie był dotychczas odrębnie omawiany. Przewijał się jednak w wielu opracowaniach, poświęconych parlamentaryzmowi polskiemu i działalności sejmików ${ }^{1}$. Podjęcie tej tematyki uzasadnione jest poszerzeniem wiedzy odnoszącej się do systemów wyborczych, zwłaszcza ich genezy. Pozwala ona dokładniej opisać i zrozumieć system wyborczy dawnej Polski, a także skorygować nieścisłości widniejące w dotychczasowych interpretacjach.

* Dr hab., Zespół Politologii i Komunikacji Społecznej, Studium Nauk Humanistycznych i Społecznych, Politechnika Wrocławska, zdzislaw.ilski@pwr.edu.pl

${ }^{1}$ Do ważniejszych prac można tu zaliczyć m.in.: Bardach i in. [1993]; Czapliński [1957]; Michalski (red.) [1984]; Olszewski [1966]; Pawiński[1978]; Prochaska [1898]; Siemieński [1906]; Śreniowski [1938]; Suchen-Grabowska, Dybkowska (red.) [1993]; Włodarczyk [1973]. 
Parlament Polski przedrozbiorowej był dwuizbowy. Senat pochodził z nominacji. Artykuł poświecony jest więc wyborowi izby poselskiej sejmu Rzeczypospolitej. Pisząc o systemie jej wyłaniania wziąłem pod uwagę główne jego elementy: podstawę terytorialną i wielkość okręgu wyborczego, formułę wybierania posłów na sejm i uprawnienia wyborców.

\section{GŁÓWNE ELEMENTY I TENDENCJE ROZWOJU SYSTEMU ELEKCJI POSŁÓW}

W dawnej Polski ważną rolę odgrywały sejmiki. Te, na których wybierano posłów, nazywano na ogół sejmikami poselskimi lub przedsejmowymi. Zbierały się w województwach, ziemiach lub powiatach i tym samym stanowiły okręgi wyborcze. Od XV wieku liczba sejmików poselskich systematycznie wzrastała. Miało to związek ze zmianami granic Polski w XVI stuleciu, przyłączeniem do Korony Mazowsza, Inflant, Podlasia i Ukrainy, z zawarciem unii lubelskiej oraz ze zniesieniem odrębności Prus Królewskich i innymi sprawami. Jeżeli więc w połowie XVI wieku zbierało się w Polsce 27 sejmików (siedem w Małopolsce, $10 \mathrm{w}$ Wielkopolsce i $10 \mathrm{w}$ województwie mazowieckim), to po zawarciu unii lubelskiej było już 69 sejmików - 44 w Koronie (20 w Wielkopolsce i na Mazowszu, 16 w Małopolsce z Ukrainą, osiem w Prusach Królewskich), 24 w Wielkim Księstwie Litewskim i jeden w Inflantach. Sieć sejmików przedsejmowych ustaliła się niemal całkowicie w XVI wieku i zasadniczo pozostała niezmieniona do początku epoki rozbiorowej [Olszewski 1966: s. 58]. Oznaczało to jednak, że nie korygowano sieci sejmików poselskich w związku z utratą ziem w następnym stuleciu i nawet po zawarciu w 1686 roku pokoju z państwem moskiewskim nadal odbywały się sejmiki egzulanckie - grupujące szlachtę ziem, które już odpadły od Rzeczypospolitej.

Słabą stroną systemu wyborczego dawnej Polski było to, że sieć sejmików nie była systematyczna pod względem geograficznym i administracyjnym. Tworzyły one układ mozaikowy. Z punktu widzenia wielkości obszaru obejmowały różnorodne terytoria - od maleńkiej ziemi gostyńskiej po ogromne województwo kijowskie. Zróżnicowanie to dotyczyło także formalno-politycznego statusu terytoriów, z których powoływano posłów. Okręgami wyborczymi były zarówno sejmiki wojewódzkie, jak i ziemskie czy powiatowe. Dostrzegalna była przy tym ewolucja, jeżeli chodzi o formowanie podstawy wybierania posłów szlacheckich. Punkt ciężkości wyraźnie przesuwał się z jednostek większych ku mniejszym. O ile bowiem na przełomie XV i XVI wieku w procedurze wyboru posłów dominowały sejmiki wojewódzkie, organizowane dla większych obszarów, tak później przewagę zyskiwały sejmiki mniejszych jednostek terytorialnych - ziem i powiatów. Na 69 sejmików już tylko 19 były to sejmiki 
wojewódzkie, a 50 - sejmiki ziem i powiatów. Ważny fakt miał miejsce zwłaszcza w Wielkim Księstwie Litewskim. Na mocy przywileju króla Zygmunta Augusta z 1565 roku terytorialną podstawą 21 z 24 sejmików stał się tu powiat sądowy, a dzięki temu cały układ sejmikowy był pod względem geograficznym usystematyzowany. Pisała Anna Sucheni-Grabowska: „Schemat litewski okazał się prosty i jednolity" [Sucheni-Grabowska, Dybkowska (red.) 1993: 132]. Dał też wyraźny wzór organizowania sejmików powiatowych i kreował tradycję wybierania posłów w powiatach. Wzmacniała ją też praktyka, iż nawet w przypadku sejmików wojewódzkich czy ziemskich wybierających większą liczbę posłów starano się respektować prawo powiatu do posiadania własnych posłów, czy posła. Tym kierowały się np. sejmiki województw sandomierskiego czy sieradzkiego [Olszewski 1966: 58-63; Płaza 1987: 79].

Brak jednolitej podstawy wybierania posłów ziemskich oznaczał w konsekwencji, że sejmiki wybierały różną liczbę posłów. W gruncie rzeczy w dawnej Polsce nie istniała ścisła norma reprezentacji, proporcjonalnie wiążąca liczbę mandatów z wielkością terytorium czy liczbą mieszkańców. O liczbie mandatów obsadzanych przez sejmiki bardziej decydowała tradycja niż przesłanki racjonalne. Realnie utarła się ona ewolucyjnie, a dużą rolę odegrał w tym zwyczaj [Pawiński 1978: 122]. Na progu parlamentaryzmu polskiego starano się ustanowić system binominalny. Za Janem Długoszem zarówno Karol Boromeusz Hoffman, jak i Antoni Prochaska twierdzili, że już od 1468 roku, w związku ze zwołaniem sejmu walnego do Piotrkowa, ustaliła się zasada, iż każdy sejmik ziemski będzie delegował po dwóch posłów [Hoffman 1988: 37; Prochaska 1898: 43, 170-176]. Rozwiązanie to nie stało się wówczas normą, pozostało jednak wzorem, którego przyjmowanie zostało rozłożone w czasie. Faktycznie posłów na sejm Polski przedrozbiorowej powoływano w małych okręgach wyborczych, liczących od dwóch do ośmiu mandatów. Wyjątkowo w Wielkopolsce województwa poznańskie i kaliskie wybierały na wspólnym sejmiku w Środzie 12 posłów. Tendencja rozwoju systemu wyborczego w zakresie wielkości okręgów wyborczych była jednak widoczna: starano się dążyć do ustanowienia systemu binominalnego - z 69 aż 42 sejmiki wybierały po dwóch posłów².

Liczba posłów na sejm nominalnie powinna oscylować wokół 182-190. Do 1764 roku mogła ona być jednak właściwie dowolna, gdyż nie została ustalona liczba przedstawicieli Prus Królewskich. Reprezentacja tego obszaru wahała się od 12 w 1695 roku do 105 w 1699 roku oraz 118 w 1730 roku [Olszewski 1966: 61]. Dopiero w 1764 roku doprecyzowano, że Prusy Królewskie będą miały 46-osobowe przedstawicielstwo, po dwóch posłów z każdego powiatu, a to pozwala ustalić liczbę krzeseł poselskich na 236 [Volumina Legum, 1860,

${ }^{2}$ Szczegółowy wykaz okręgów wyborczych w Rzeczypospolitej w latach 1692-1763 widnieje w [Olszewski1966: 64-66]. Zob. też [Michalski (red.) 1984: 68-69; Bardach i in. 1993: 28]. 
t. VII: 10; . Leśnodorski 1947: 37]. Z kolei sejm nadzwyczajny obradujący w 1767/1768 roku zwiększył reprezentację województw poznańskiego i kaliskiego, z 12 do 20 posłów, a tym samym ogólna liczba posłów sejmowych wzrosła do 244. Nasilające się od drugiej połowy XVII wieku zrywanie sejmików poselskich sprawiało, że faktyczna liczba posłów była jednak różna. Normalnie na sejm przybywało $120-150$ przedstawicieli sejmików [Olszewski 1966: 101].

Ważnym elementem systemu wyborczego Polski przedrozbiorowej był też sposób wybierania posłów przez sejmiki. W drugiej połowie XVI i w pierwszej połowie XVII wieku izba poselska górowała znaczeniem nad senatem; w niej spoczywał punkt ciężkości polityki państwa. Przywiązywano więc wagę do trybu jej powoływania. Badacze zgodnie twierdzą, że do 1768 roku całe postępowanie sejmikowe opierało się nie na prawie stanowionym, lecz na zwyczaju i podejściu pragmatycznym, w którym życie przeważało nad formą [Siemieński 1906: 46; Śreniowski 1938: 9; Włodarczyk 1973: 159-166; Kriegseisen 1991: 51]. Tym samym do czasów stanisławowskich dawna Polska nie ujednoliciła oraz nie sformalizowała zasad wybierania posłów. Procedury wyborcze były zdecentralizowane, a o zasadach wybierania posłów zasadniczo decydowały sejmiki - samodzielnie i niezależnie od siebie.

$\mathrm{W}$ procedurze powoływania posłów początkowo kierowano się zasadą jednomyślności; wybór unanimi consensu był prawem podstawowym i wyjściowym. W wielu wypadkach sejmiki zdobywały się rzeczywiście na jednomyślną - często w postaci aklamacji - elekcję posłów. Szlachta wysoko szacowała wybór „chwalebną jednomyślnością”, postrzegała ją jako „znak łaski Bożej” [Włodarczyk 1973: 169]. Wybór w tym trybie był realnie trudny do osiągnięcia. Stanisław Śreniowski zauważył, że w tym stanie rzeczy, to nie zasada jednomyślności, będąca wyrazem aktywności grupy, lecz zasada zgody, jako bardziej pasywna, a tym samym łatwiejsza w operowaniu, stała się na sejmiku główną zasadą podejmowania decyzji. Jego zdaniem nie były one sobie zresztą przeciwstawne, wyznaczały dwie odmienne sytuacje podejmowania przez sejmik decyzji [Śreniowski 1938: 98-99].

Jednakowoż także wybór na zasadzie zgody oznaczał w praktyce różne możliwości elekcji posłów. Po pierwsze, starano się w ramach debaty sejmikowej przedyskutować i wspólnie ustalić, kto będzie posłem na sejm. W tym trybie postępowania operowano też „braterską perswazją”. Polegała na skłanianiu kandydatów słabo popieranych do rezygnacji z ubiegania się o mandat, z czym często łączyła się obietnica wyboru przy „kolejnej okazji”. Tym sposobem wybierano osoby wspólnie uzgodnione i wówczas elekcja była faktycznie jednozgodna. Po drugie, wybór jednozgodny następował wówczas, gdy większość była za określonymi kandydaturami, a mniejszość - chociaż miała inną preferencję wyborczą - nie kontestowała woli większości. W tym wypad- 
ku realnie działała zasada nemiene contradicente, brak sprzeciwu. Operowano nią od połowy XVII i przez cały XVIII wiek. Traktowano ją też jako główny miernik zgodnych wyborów [Śreniowski 1938: 102]. Po trzecie, wybór jednozgodny następował i wtedy, gdy większość w różnej formie przymuszała mniejszość do respektowania swej woli lub też przechodzono nad sprzeciwem do porządku dziennego i nie uwzględniano go. Po czwarte wreszcie, w sytuacji występowania silnego napięcia na sejmiku, godzono się dzielić mandaty pomiędzy skonfliktowane siły i w ten sposób osiągać swoisty „zgodny wybór”’3. Dosyć specyficzną ilustracją ostatniego przypadku był wybór posłów na sejm dokonany w 1584 roku przez sejmik proszowicki. Widnieje ona w opracowanym przez Józefa Siemieńskiego Dyaryuszu sejmiku proszowskiego przedsejmowego roku 1584. Sejmik ten wyłaniał sześciu posłów z województwa krakowskiego. W 1584 roku zebrał się w trudnym momencie historycznym, krótko po straceniu Samuela Zborowskiego, przedstawiciela ważnego rodu możnowładczego. Okoliczność ta zaważyła na niezwykle burzliwym przebiegu sejmiku, obradującym w warunkach obecności uzbrojonych osób. Przeważali na nim zwolennicy rodu Zborowskich, a mniejszością byli stronnicy Jana Zamoyskiego, naówczas kanclerza wielkiego koronnego i hetmana wielkiego koronnego. Podczas wyboru posłów bez większych trudności ustalono nazwiska pięciu posłów - czterech z obozu Zborowskich i jednego z obozu hetmańskiego. Zwaśnione strony nie mogły jednak osiągnąć zgody odnośnie do ostatniego posła, każdy z obu obozów chciał mieć swojego przedstawiciela. Mimo napiętej atmosfery, grożącej wybuchem starcia zbrojnego, zdołano osiągnąć porozumienie. Polegało na tym, że zgodzono się obrać obu spornych kandydatów i w sumie wybrano nie sześciu, lecz siedmiu posłów - pięciu z formacji Zborowskich i dwóch stronników J. Zamoyskiego [Dyaryusz sejmiku..., 1912: 317-332]. Rozstrzygnięcie to było specyficzne, bo wybór jednozgodny został osiągnięty na drodze samowolnego zwiększenia, o jeden, puli mandatów przysługujących województwu krakowskiemu.

Szlachta polska była przywiązana do zasady jednomyślności/jednozgodności. Doceniano jej tradycyjną rolę w przeszłości, pochwalano funkcje w zakresie ochrony wolności i równości szlacheckiej, respektowania praw mniejszości i opozycji, a za tym pozytywną rolę w integracji wielonarodowej Rzeczypospolitej. Zasada jednozgodności była też wyrazem sprzeciwu wobec mechaniczno-liczbowego rozstrzygania ważnych kwestii, szlachta ceniła sobie rozważanie ich na drodze debaty, dialogu, perswazji i kompromisu, a ponadto aprobowała myśl, że głosy nie tylko należy liczyć, ale i ważyć [Michalski (red.) 1984: 141-144; Bardach i in. 1993: 64-65; Olszewski 2002: 272; Dzięgielewski 1993: 77-79].

${ }^{3}$ Obszerniej o procedurze wyborczej w [Michalski (red.) 1984: 137-144]; Czapliński [1957: 230]; Śreniowski [1938: 98-111]; Włodarczyk [1973: 131]. 
Na dłuższą metę utrzymanie zasady jednozgodności okazało się jednak niemożliwe. Dla zmiany sposobu myślenia szlachty w tej sprawie, szczególnie istotne okazały się względy pragmatyczne, a głównie fatalne często działanie zasady jednozgodności na poziomie lokalnym, w sprawach związanych z bliskimi interesami szlachty. Ważną ścieżką rozwoju demokracji w dawnej Polsce była możliwość samorządzenia się ziem i województw. W jej ramach szlachta miała możliwość wybierania z własnego grona kandydatów na ważnych urzędników ziemskich, zwłaszcza podkomorzych, sędziów, podsędków czy pisarzy ziemskich. Na funkcje owe wybierała po czterech kandydatów, spośród których król powoływał jedną osobę. Początkowo starano się dokonywać tego wyboru na zasadzie jednomyślności, co z biegiem lat stawało się coraz trudniejsze. Zdarzało się, że czasem przez szereg lat dany urząd nie był obsadzany; urząd ważny właśnie z punktu widzenia bieżących potrzeb szlachty. Podobnych trudności przysparzał wybór przedstawicieli ziemi do Trybunału Koronnego dokonywany na tzw. sejmikach deputackich [Pawiński 1978: 390-399; Kriegseisen 1991: 137-168; Choińska-Mika 1998: 33-38]. Ciekawą obserwację poczynił Józef Siemieński zaznaczając, że zrywanie sejmików następowało najczęściej właśnie na sejmikach wyborczych, a nie stosowano liberum veto na sejmikach rozstrzygających sprawy merytoryczne [Siemieński 1906: 50; Włodarczyk 1973: 169-175].

Z czasem doszedł do tego kolejny element. Już w XVI wieku, zwłaszcza w okresie działania ruchu egzekucyjnego, sejmiki stały się widownią ostrych starć pomiędzy magnaterią a szlachtą, a później także pomiędzy koteriami magnackimi oraz miejscem korumpowania szlachty. Jednozgodny wybór posłów stał się niesłychanie trudny. W sytuacji braku zgody intuicyjnie odwoływano się do rozstrzygnięcia większościowego. Nie było ono jednak regułą formalną i kandydaci przegrywający nie zawsze godzili się z porażką. Prowadziło to więc czasem do wyboru podwójnego składu posłów i praktyki rugowania części z nich przez sejm [Płaza 1987: 83-84]. Od połowy XVII wieku życie sejmikowe zaczęło też ulegać stopniowej patologizacji, w której ramach dokonywało się na większą skalę zrywanie sejmików przedsejmowych. Jeżeli w 1669 roku na sejmie nie było przedstawicieli tylko 10 sejmików, tak w czasach saskich liczba zrywanych sejmików mogła dochodzić już do kilkudziesięciu; np. w 1732 roku zerwano - ekstremalnie - aż 39 sejmików poselskich [Olszewski 1966: 76-77]. Szlachta zaczęła więc także orientować się, że zasada wyboru jednomyślnego stawała się dysfunkcjonalna dla mechanizmu działania państwa. Zrywanie sejmików wyborczych zachwiało powszechną dawniej aprobatą dla wyborów jednomyślnych. Szlachta dostrzegła anarchizujący wpływ tej zasady na funkcjonowanie mechanizmu państwa, a także na znacznie jej bliższe działanie instytucji ziemskich. 
Stopniowo więc w procedurach wyborczych zaczęła sobie torować drogę zasada głosowania większościowego. Według J. Siemieńskiego, jej wprowadzenie przebiegało w dwóch fazach. Pierwsza przebiegała w XVII wieku, a kolejna w drugiej połowie XVIII wieku [Siemieński 1906: 48]. Jako pierwsze przyjęły ją w 1598 roku sejmiki województwa mazowieckiego. W 1611 roku postanowienie sejmu, że wybory posłów na sejm będą przeprowadzane większością głosów otrzymały sejmiki województw sieradzkiego i krakowskiego oraz sejmiki ziem wieluńskiej i chełmskiej. W 1613 roku podobne decyzje uzyskały sejmiki Wielkiego Księstwa Litewskiego, sejmiki województw kijowskiego i płockiego oraz ziemi łęczyckiej. Pod koniec XVII wieku większościowy tryb elekcji posłów wprowadziły jeszcze województwo podlaskie (w 1681 r.) i województwa kujawskie (w 1685 r.). Ostatecznie więc większość sejmików - przynajmniej 45 na 69 - wprowadziła większościowy tryb elekcji. Chociaż przyjęcie przez sejmik większościowej formuły wyborczej wymagało aprobaty sejmu, to głos decydujący w tej kwestii należał jednak do samego sejmiku; sejm potwierdzał wolę szlachty z danego terytorium. Od razu też stosowano tę formułę do wyboru posłów, jak też do wyłaniania kandydatów na urzędy, przedstawicieli szlachty w trybunale i sądach kapturowych. W tych sejmikach, które wdrożyły formułę większościową, głosowano jawnie, a marszałek sejmiku stawiał kreskę przy nazwisku kandydata, na którego głos został oddany; w XVIII wieku obliczanie głosów stało się obowiązkiem asesorów. Do elekcji wystarczyło uzyskanie względnej większości głosów [Siemieński 1906: 48-49; Olszewski 1966: 98; Włodarczyk 1973: 131; Kriegseisen 1991: 60].

Tak więc już w XVII stuleciu większościowa formuła wyborcza zaczęła być ważna w systemie politycznym Polski. Trzeba jednak widzieć, że przyjmowała się ona powoli i z pewnymi oporami. Szlachta postrzegała ją ambiwalentnie. Doceniała z jednej strony jej efektywność w procedurze wyborczej, lecz z drugiej strony - czasem uważała ją za zagrożenie dla wolności, która w mniemaniu szlachty osadzona była właśnie na zasadzie jednozgodności, a nie większości. Szlachta także dostrzegała, że większościowa formuła elekcji posłów nie chroni przed tumultami i zrywaniem sejmików [Siemieński 1906: 52; Śreniowski 1938: 109; Olszewski 1966: 208, 307 309; Włodarczyk 1973: 131-132, 171].

Stąd też płynęła znamienna ostrożność i pewna niekonsekwencja w operowaniu nią. Jak pisał Adolf Pawiński, sejmik kujawski wprowadził ją na przykład dopiero w 1685 roku, ale była podważana i na sejmiku tym jeszcze długo potem starano się podejmować decyzje i wybierać posłów na zasadzie jednozgodności [Pawiński 1978: 78 - 81, 126, 401, 479-483]. Z kolei szlachta ziemi dobrzyńskiej do epoki stanisławowskiej nie żądała zmiany procedury wyboru posłów, zgodę na operowanie formułą większościową uzyskała dopiero w 1766 roku, ale w ogóle z niej nie korzystała i tradycyjnie wybierała na zasadzie jednozgodności [Siemieński 1906: 49-53]. 
Sejmiki, które formalne nie przyjęły większościowej metody powoływania posłów nie miały sformalizowanych zasad wyborczych. Operowały też różnymi sposobami ich elekcji. Większość z nich pozostała przy praktyce jednozgodnego ich powoływania, niektóre wybierały na podstawie formuły większościowej. W tej grupie sejmików zdarzało się, że stosowano kombinowany system wyboru posłów: jeżeli tryb wyboru jednozgodnego zawodził, to elekcję posłów można było przeprowadzić na podstawie formuły większościowej ${ }^{4}$. Jednak także i to oznaczało różne możliwości wyboru posłów. Sejmik województwa ruskiego w Sądowej Wiszni w 1720 roku przyjął, że jeżeli zawiedzie tryb wyboru jednozgodnego, to za zgodą uczestników sejmiku wybory posłów zostaną przeprowadzone metodą większościową [Olszewski 1966: 99-100].

Kombinacyjny system mógł znaleźć również jednoczesne zastosowanie na tym samym sejmiku i w odniesieniu do różnych kandydatur. Ilustruje to przebieg wyboru czterech posłów ziemi łęczyckiej w 1613 roku. Sejmik wybrał trzech posłów na zasadzie zgody, a czwartego w wyborach większościowych [Włodarczyk 1973: 169].

Ostatecznie więc już w XVII wieku system wyborczy do izby poselskiej został oparty na różnych sposobach elekcji przedstawicieli sejmików, operowano zasadami jednozgodności większości głosów lub praktyczną kombinacją tych zasad. Część szlachty zdawała sobie sprawę z tego, że jest to słaba strona systemu politycznego i domagała się - długo bezskutecznie - wprowadzenia jednolitego sposobu wyboru posłów; żądanie takie wystąpiło, np. w 1690 roku w instrukcji sejmiku kujawskiego, ułożonej dla nowo wybranych posłów [Olszewski 1966: 99].

Ważna wydaje się tu być jeszcze refleksja dotycząca relacji między zasadami wyborów jednozgodnych a większościowych oraz postrzeganie tej relacji przez samą szlachtę. W odczuciu szlachty wybory jednozgodne nie kolidowały wcale z wyborami większościowymi [Olszewski 1966: 98-101]; dla niej „tem lepszy był wybór, im więcej nad większość zjednoczył" [Śreniowski 1938: 111]. Wydaje się, że szlachta wyraźnie też unikała kategorycznego wartościowania obu tych zasad [Olszewski 1966: 98-101]. W życiu politycznym postępowała elastycznie, często odwoływała się do rozwiązań pragmatycznych. Chociaż bliższe jej było dokonywanie wyborów na podstawie zgody, to jednak doceniała efektywność zasady większości. W sumie traktowała obie zasady wyborcze jako komplementarne. Właśnie dlatego często gotowa była operować kombinacją tych zasad. Starała się przeprowadzić wybory zgodnie, a jeżeli to zwodziło, stosowała tryb większościowy [Kriegseisen 1991: 60; Choińska-Mika 1998: 30-31; Rzążewski i in 2014: 75].Trzeba zauważyć, że ta elastycz-

${ }^{4} \mathrm{~Np}$. sejmik halicki nie wprowadził formalnie większościowej formuły wybierania posłów, ale tak właśnie ich wybrał w latach 1699, 1701, 1712 [Śreniowski 1938: 110]. 
na i pragmatyczna skłonność operowania systemem kombinacyjnym widoczna była zarówno w tych sejmikach, które przyjęły większościowy sposób wyboru posłów, jak i w tych, które tradycyjnie za punkt wyjścia traktowały wybory jednozgodne. Można więc zaliczyć skłonność i praktykę operowania kombinacyjnym sposobem elekcji posłów do wzoru systemu wyborczego Polski przedrozbiorowej.

W pracach dotyczących procedur elekcyjnych w dawnej Polsce jest niewiele informacji o uprawnieniach wyborcy, czasem trudno w nich znaleźć odpowiedź na pytanie o liczbę głosów, które mógł oddać szlachcic uczestniczący w wyborze posła na sejmiku. Elekcji dokonywano w okręgu wielomandatowym. Większościowa formuła wyborcza może w nim być stosowana w kilku wariantach: 1) może przybrać postać głosowania ograniczonego, w którym wyborca ma mniej głosów niż jest miejsc do obsadzenia; 2) może być realizowana w formie głosowania blokowego, w którym wyborca ma tyle głosów, ile mandatów jest do obsadzenia; 3) może też być wyrażana poprzez głosowanie aprobujące, w którym wyborca może udzielić poparcia dowolnej liczbie zgłoszonych kandydatów. Nieliczne źródła i prace opisujące dokonywanie wyborów poselskich na sejmikach wydają się wskazywać, że w tych sejmikach, które przyjęły większościową formułę wyborczą, znalazł zastosowanie system głosowania blokowego, w wersji otwartej. Jest to większościowy system wyborczy, wybory przeprowadza się w okręgach wielomandatowych, wyborca ma tyle głosów, ile mandatów jest do obsadzenia, nie może kumulować głosów, oddaje je na konkretne osoby, bez możliwości przeniesienia głosów na innych kandydatów, a do elekcji potrzebne jest uzyskanie większości względnej [Sokala $i$ in. 2013: 228]. Tak też wybierał posłów polski szlachcic - wyborca: oddawał tyle głosów, ilu posłów dany sejmik mógł obrać, jego głosy były zapisywane kreskami przez marszałka sejmiku (od XVIII w. przez asesorów), a do elekcji wystarczyła większość względna. Z zachowanego w archiwaliach rodziny Morsztynów w Bibliotece Narodowej opisu przebiegu sejmiku proszowickiego w 1689 roku wynika, że w ten właśnie sposób dokonano na nim elekcji posłów na sejm w 1690 roku$^{5}$.

W okresie poprzedzającym epokę rozbiorów ówczesna Polska miała system wyłaniania izby poselskiej. Był on jednak ułomny. Za wyjątkiem Wielkiego Księstwa Litewskiego, sieć sejmików poselskich nie była usystematyzowana pod względem polityczno-administracyjnym i geograficznym. Sejmiki wybierały różną liczbę posłów i nie było to związane z racjonalną normą reprezentacji.

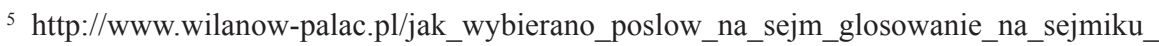
przedsejmowym_w_proszowicach_w_1689_r.html. Prawdopodobieństwo stosowania systemu głosowania blokowego sygnalizował także Śreniowski [1938: 110], opisując dokonywanie wyboru przez sejmik halicki czterech kandydatów na urzędy ziemskie.
} 
Niejednolite były też zasady powoływania przedstawicieli szlachty. Praktyka elekcji posłów na sejm w dawnej Polsce już do końca XVII wieku wykreowała jednak dosyć widoczny wzór systemu wyborczego. Wybijały się w nim następujące kluczowe elementy. Po pierwsze, w aspekcie polityczno-administracyjnym podstawą wyboru posłów starano się czynić sejmiki mniejszych jednostek terytorialnych - ziem i powiatów. Po drugie - z punktu widzenia wielkości okręgu wyborczego - za wyjątkiem Wielkopolski - posłów wybierano w okręgach małych, liczących od jednego do ośmiu mandatów; ponad połowa sejmików wybierała po dwóch posłów. Po trzecie - z punktu widzenia formuły wyborczej system elekcji posłów starano się oprzeć na kombinacji zasady jednozgodności i zasady większości; w przypadku stosowania trybu większościowego regułą rozstrzygnięcia była większość zwykła, otrzymywana na ogół w głosowaniu jawnym, potwierdzonej odpowiednią liczbą kresek stawianych przy nazwiskach kandydatów. Po czwarte - w aspekcie uprawnień głosującego operowano systemem głosowania blokowego: szlachcic - wyborca mógł oddać tyle głosów, ile mandatów poselskich było do obsadzenia.

\section{IMPLEMENTACJA W REFORMIE USTROJU POLITYCZNEGO POLSKI PODJĘTEJ PRZEZ SEJM CZTEROLETNI}

Zarysowany przez praktykę polityczną wzór systemu wyborczego do sejmu uwzględniany był dalej przez polską myśl polityczną, przygotowującą grunt pod głęboką zmianę systemu politycznego państwa. Znalazł też zastosowanie w reformach podjętych w czasie panowania króla Stanisława Augusta Poniatowskiego, a zwłaszcza w planie reform państwa polskiego przyjętym przez Sejm Wielki (1788-1792). Zawarty w nich koncept uzdrowienia parlamentaryzmu polskiego zwierał nie tylko rozwiązania odnoszące się do trybu podejmowania decyzji sejmowych, znoszące liberum veto i wprowadzające głosowanie większościowe. Dostrzeżono także potrzebę ustanowienia jednolitego systemu wyborczego.

Zmiany w tym zakresie następowały stopniowo, ale już od samego początku epoki stanisławowskiej. Wyraźnie też nawiązywały do wzoru systemu wyborczego wypracowanego do końca XVII wieku. Torował sobie drogę system binominalny: konstytucja sejmu konwokacyjnego w 1764 roku stanowiła, że trzy województwa pruskie będą wysyłały stałą liczbę posłów - po dwóch z powiatu, a na sejmie nadzwyczajnym w 1767/1768 roku postanowiono, że posłowie $\mathrm{z}$ Wielkopolski będą wybierani na trzech sejmikach wojewódzkich, ale po dwóch z każdego powiatu [Volumina Legum, 1860, t. VII: 10, 155; Siemieński 1905: 11, 49 - 50; Kriegseisen 1991: 261]. 
Także podczas obrad sejmu 1767/1768 roku ustanowiono jednolity tryb wybierania posłów. Prawa wyborcze uzyskała szlachta powiązana z ziemią danego sejmiku. Czynne prawo wyborcze oznaczono dla wieku 18 lat, a bierne - 23 lata. W procedurze wyboru posłów broniła się, zaczerpnięta $\mathrm{z}$ wypracowanego wcześniej wzoru, kombinacja wyborów jednozgodnych i większościowych. Konstytucja sejmu stanowiła bowiem, że dla wyboru posłów, a także na inne funkcje wybieralne, w pierwszej kolejności należało szukać rozstrzygnięcia jednozgodnego. W sytuacji, gdy wybór nie był zgodny, należało przeprowadzić głosowanie większościowe. $Z$ opisu procedury wynika, że każdy pełnoprawny uczestnik sejmiku oddawał głos w sposób jawny, zapisując swoją preferencję na karcie wyborczej konkretnych kandydatów [Volumina Legum, 1860, t. VII: 293-294]. Na podstawie tego opisu trudno jest jednak ustalić, ile głosów mógł oddać szlachcic - wyborca; prawdopodobnie chodziło o głosowanie blokowe. Sejm z 1767/1768 roku wprowadził kombinację jednozgodności z tajnym głosowaniem większościowym także w kwestiach merytorycznych: „Na sejmikach, osobliwie poselskim, wszelkie materie, gdy się per unanimitatem nie zgodzą, per turnum pluralitate traktowane być mają..." [Volumina Legum, 1860, t. VII: 294].

Jednolity dla całego państwa system wyłaniania izby poselskiej sejmu ustanowiono dopiero w ramach przyjmowania Konstytucji 3 maja. Nie został on jednak zawarty w samej Konstytucji, gdyż miała ona charakter ramowy, wskazujący jedynie podstawy ustroju politycznego Rzeczypospolitej. Na przyjęty w 1791 roku system wyborczy składały się regulacje zawarte zasadniczo w czterech ustawach Sejmu Wielkiego. Pierwszą z nich była ustawa pt. Sejmiki, na ogół nazywana prawem o sejmikach, uchwalona 24 marca 1791 roku i potwierdzona w Konstytucji 3 maja. Wprowadziła ona rozwiązania systemowe poczynań sejmików wybierających posłów na dwuletnią kadencję sejmu. Miały odbywać się co dwa lata w stałym miejscu i terminie (18 sierpnia), począwszy od 1792 roku. Obrady miały trwać zasadniczo od godziny dziewiątej rano do trzeciej po południu. Od udziału w sejmikach wyłączono szlachecką służbę magnacką, szlachtę gołotę i większość dzierżawców. Uczestnikami sejmiku byli szlachcice ujęci w Księdze ziemiańskiej, która powinna być utworzona na terenie każdego sejmiku i de facto była spisem wyborców. Czynne prawo wyborcze miało przysługiwać od 18 roku życia, a bierne od ukończenia 23 lat. Ustanowiono też procedurę poczynań sejmiku, w tym również sposób wyboru posłów. Każdy uprawniony do korzystania z biernego prawa wyborczego mógł sam zgłosić pisemnie swoją kandydaturę przed sejmikiem lub na początku jego obrad, ale kandydatury mogły też być swobodnie wysuwane przez innych uczestników sejmiku. Lista osób kandydujących powstawała na samym początku jego obrad. Procedura wyborcza przewidywała zastosowanie występującej we wzorze kombinacji jednozgodności z wyborami większościowymi. 
Co więcej, uczyniła ją wręcz zasadą. Zarazem też dokładniej ją prezentowała. W pierwszej kolejności marszałek sejmiku miał „szukać” rozstrzygnięcia jednozgodnego. Mianowicie odczytywał z listy kandydaturę i trzykrotnie pytał sejmik o zgodę na jej elekcję. Jeżeli uczestnicy nie sygnalizowali obiekcji wobec kandydata, marszałek $\mathrm{z}$ asesorami jedynie odnotowywali ten fakt, bo nie oznaczało to jeszcze ostatecznego wyboru. Rozstrzygnięcie jednozgodne miało być bowiem skuteczne tylko wówczas, gdy sejmik zgodnie wyłoni wszystkich posłów. Jeżeli jednak nie byłoby zgody na któregoś z kandydatów, to na żądanie uczestników sejmiku, w tym pisemne żądanie nawet jednego szlachcica, marszałek powinien przeprowadzić głosowanie tajne na wszystkich kandydatów [Volumina Legum, 1889, s. t. IX: 233-236, 240-241].

Procedura głosowania tajnego została precyzyjnie wskazana. Nakazywała jego przeprowadzenie przy użyciu gałek (liczba równa liczbie sejmikujących) i dwukomorowej urny (komora affirmativé i komora negativé), zamkniętej na dwa klucze. Tok postępowania miał być następujący: 1) nazwisko każdego z kandydatów było zapisane na odrębnej kartce, którą wrzucano do naczynia, a „dziecię" miało kolejno losować owe kartki; 2) po wylosowaniu pierwszego nazwiska, jako pierwszy oddawał głos marszałek sejmiku. Polegało to na tym, że otrzymywał od jednego z sześciu asesorów gałkę, którą wrzucał do urny, a ściślej do jednej z dwóch komór - albo do tej, w której akceptowano, albo do tej, w której odrzucano danego kandydata. Tak też postąpić miał każdy inny uczestnik sejmiku; 3) kiedy wszyscy - wyczytywani przez asesorów z księgi ziemian - uczestnicy sejmiku oddali głosy na pierwszego wylosowanego kandydata, urna była otwierana i marszałek z asesorami liczyli gałki - osobno z komory afirmującej i osobno z komory negującej - a wynik głosowania był zapisywany; 4) po przeprowadzeniu głosowania na pierwszego wylosowanego kandydata, „dziecię" losowało kolejnego kandydata i dalsze postępowanie było identyczne jak w przypadku pierwszej kandydatury. W taki sposób postępować należało też ze wszystkimi pozostałymi kandydaturami; 5) po zakończeniu procedury losowania kolejności wybierania, oddawania głosów na poszczególne kandydatury, przeliczaniu i zapisaniu wyników, marszałek z asesorami tworzył rejestr kandydatów zaczynając od tego, który otrzymał najwięcej głosów poparcia, potem kolejno, po czym wskazywał, którzy kandydaci z największym poparciem zostali wybrani posłami. Do elekcji wystarczyła więc większość zwykła; 6) w przypadku remisu przewidziane było, kolejne głosowanie, ale dotyczyć miało już tylko kandydatów z takim samym poparciem. Wszystkie czynności związane z wyborem posłów mogły być swobodnie monitorowane przez kandydatów [Volumina Legum, 1889, t. IX: 236-241]. Po wyborze posłów toczyć się miała debata nad instrukcją. Prawo o sejmikach przewidywało także możliwość odwołania posła na sejmiku relacyjnym - głosowanie miało odbywać się na pisemny wniosek jego uczestnika, popartego przez 12 innych sejmikujących [Volumina Legum, 1889, t. IX: 233-240; Kriegseisen 1991: 264-265]. 
Przedstawiona w prawie o sejmikach procedura wyborcza wydaje się wskazywać, że z punktu widzenia uprawnień wyborcy reformatorzy polscy zastosowali w tajnym głosowaniu większościowym nowatorskie rozwiązanie: miał to być system głosowania aprobującego. Do takiego twierdzenia upoważniają dwie okoliczności. Po pierwsze - prawo o sejmikach nie wskazywało, ile głosów pozytywnych mógł oddać uczestnik sejmiku. Po drugie - każdy szlachcic wyborca był zapraszany przez asesora do oddania głosu odrębnie na każdą ze zgłoszonych kandydatur. Ponieważ głosowanie miało być tajne - miało polegać na wrzucaniu gałki do dwukomorowego naczynia wyborczego - co oczywiście mogło prowadzić do sytuacji, że szlachcic wyborca mógł wrzucić gałkę do komory aprobującej właściwie dla dowolnej liczby kandydatów, nawet dla wszystkich. Na tym etapie badań trudno jest mi jednak rozstrzygnąć, czy twórcy Konstytucji 3 maja świadomie zastosowali głosowanie aprobujące. Prawdopodobnie znali je, gdyż rudymenty systemu głosowania aprobującego występowały wcześniej w historii: w procedurze wyboru papieży, w praktyce wyborczej Wenecji i Raguzy [Rzążewski i in. 2014: 24, 32-36, 55-56, 112]. Raczej wiedział o tym ks. Hugo Kołłątaj - główny architekt nowego systemu wyborczego w Polsce. Być może jednak autorzy nowego prawa wyborczego w Rzeczypospolitej nie precyzowali kwestii uprawnień wyborcy, bo za oczywiste uważali, że zachowa się on zgodnie z logiką głosowania blokowego, czyli odda tyle głosów, ile mandatów będzie do obsadzenia; takie rozwiązanie intuicyjnie nawiązywało do wzoru wytworzonego już wcześniej. W tej kwestii potrzebne są dalsze badania.

Z kolei w kwietniowej ustawie z 18 kwietnia 1791 roku pt. Miasta nasze królewskie wolne w państwach Rzeczypospolitej, włączonej do Konstytucji 3 maja, przyjęto, że 24 miasta, będące siedzibą sądów apelacyjnych, wybiorą sposobem większościowym po jednym plenipotencie na sejm, zawężając jednakże pole ich aktywności do obrad kilku komisji sejmowych [Miasta nasze królewskie..., 1997: 140]. W ustawie z 24 czerwca 1791 roku noszącej tytuł Urzadzenie wewnętrzne miast wolnych Rzeczypospolitej w Koronie $i$ Wielkim Księstwie Litewskim dopowiedziano jednak, że wybory plenipotentów miały być pośrednie, oparte na tym samym trybie, co wybory posłów ziemskich, a więc na kombinacji zasad jednozgodności i większości [Volumina Legum, 1889, t. IX: 291-293]. Natomiast w dniu 2 listopada 1791 roku Sejm Wielki przyjął ustawę pt. Rozkład województw, ziem i powiatów, z oznaczeniem miast, a w nich miejsc konstytucyjnych dla sejmików w prowincjach koronnych $i$ Wielkiego Księstwa Litewskiego, wprowadzającą jednolitą podstawę elekcji i liczbę posłów. W myśl jej postanowień każda prowincja państwa polskiego - Wielkopolska, Małopolska i Wielkie Księstwo Litewskie - uzyskała po 68 posłów, co w sumie kreowało izbę poselską na poziomie 204 deputowanych. Wybierać ich miano na 102 sejmikach, po dwóch posłów z każdego Oznaczało to potrzebę 
powołania sejmików mniejszych. Tylko w pięciu przypadkach były to sejmiki wojewódzkie (województwa: bełzkie, mińskie, połockie, brzesko-kujawskie, inowrocławskie). Pozostałe sejmiki obejmowały od jednego do kilku powiatów (ziem) [Volumina Legum, 1889, t. IX: 326-338; Kriegseisen 1991: 265-269]. Dla przykładu, w województwie łęczyckim zamiast dotychczasowego jednego sejmiku wojewódzkiego utworzono dwa sejmiki przedsejmowe. Powiaty orłowski i łęczycki miały obradować w Łęczycy i wybierać dwóch posłów; taką samą liczbę posłów miały powoływać powiaty brzeziński i inowłodzki na sejmiku w Brzezinach [Włodarczyk 1973: 25]. Walorem przyjętych naówczas rozwiązań było z pewnością ustanowienie jednolitego systemu powoływania izby poselskiej sejmu, a słabą stroną to, że został on ujęty w kilku, a nie w jednym akcie prawnym.

W sumie więc, w 1791 roku w ramach reformowania ustroju politycznego Rzeczypospolitej przyjęto jednolity system wyborczy do izby poselskiej. Można go opisać następująco: 1) z punktu widzenia swej podstawy oparto go zasadniczo na sejmikach mniejszych obszarów - powiatów/ziem; 2) w aspekcie wielkości okręgu był systemem binominalnym (tylko w miastach były okręgi jednomandatowe), 3) z punktu widzenia reguły rozstrzygnięcia oparto go na kombinacji wyborów jednozgodnych z zasadą wyborów większościowych (większość względna), 4) biorąc pod uwagę uprawnienia wyborcy - w przypadku wyborów większościowych - był to system głosowania aprobującego. Znalazł zastosowanie w wyborach urzędników lokalnych, które przeprowadzono w lutym - marcu 1792 roku.

Konfederacja targowicka i przegrana wojna z Rosją w 1792 roku przekreśliły dzieło Sejmu Wielkiego. Zebrany w 1793 roku sejm grodzieński przyjął w ramach Praw kardynalnych, ustanowionych w dniu 23 listopada 1793 roku, nowe rozwiązania ustrojowo-konstytucyjne, w tym system wyborczy. Podstawą wyboru posłów stał się nowy podział administracyjny Polski. Została ona podzielona na województwa (10 w Koronie i osiem na Litwie), a każde z nich dzieliło się na trzy ziemie. Każde województwo miało mieć jednolicie równą reprezentację parlamentarną: po dwóch senatorów (wojewoda i kasztelan) oraz po sześciu posłów, po dwóch z każdej ziemi. Podstawa wyboru posłów była już mniej jednolita. W sześciu województwach Korony - krakowskim, sandomierskim, wołyńskim, chełmskim, włodzimierskim i lubelskim - posłów obierać miano na sejmiku wojewódzkim. Natomiast w pozostałych czterech województwach - mazowieckim, warszawskim, ciechanowskim i podlaskim - posłów miały wybierać sejmiki ziem/powiatów, każdy po dwóch reprezentantów. Także na Litwie każdy powiat miał wybierać po dwóch posłów. W sumie więc izba poselska sejmu miała liczyć 108 posłów, 60 z Korony i 48 z Litwy [Volumina Legum, 1952, t. X: 315-316]. 
Przyjęte w Prawach kardynalnych rozwiązania regulowały również sposób wybierania izby poselskiej sejmu i - co ciekawe - utrzymały szereg rozwiązać uchwalonych w 1791 roku. Uderzające było to, że wprowadzono odrębne procedury wyboru posłów dla Korony i Wielkiego Księstwa Litewskiego. Generalnie były porównywalne, różniły się jednak w pewnych konkretnych rozwiązaniach. Na obu obszarach sejmiki poselskie miały zbierać się raz na cztery lata, w tych samych miastach, a w nich w ustalonych miejscach. Utrzymano warunki uczestnictwa $\mathrm{w}$ sejmiku oraz korzystania z czynnego i biernego prawa wyborczego; zachowano też spis wyborców w postaci Ksiegi ziemiańskiej. Procedura elekcji posłów nakazywała operowanie kombinacją wyborów jednozgodnych i większościowych. Po przedstawieniu listy kandydatów, marszałek sejmiku osobno dla każdej kandydatury miał trzykrotnie zapytać jego uczestników o zgodę na jej wybór. W odróżnieniu od rozwiązań przyjętych w 1791 roku, jeżeli dana kandydatura została zgodnie wybrana, to takie rozstrzygnięcie było już wiążące. Jeżeli nie wszystkie mandaty zostały obsadzone w trybie jednozgodności, to do mandatów w ten sposób nie obsadzonych należało przeprowadzić tajne głosowanie większościowe [Volumina Legum, 1952, t. X: 119-123, 127-133].

Procedury tajnego głosowania większościowego dla obu prowincji różniły się. W Koronie miały być sporządzone karty wyborcze, osobne dla każdego kandydata. Na tych kartach uczestnicy sejmiku, wzywani przez asesorów „porządkiem parafii” z księgi ziemiańskiej, mieli wpisywać bądź zaznaczać swoją preferencję. W tym punkcie procedura wyborcza nie była precyzyjna. Powstaje wątpliwość, czy w świetle jej opisu głosowanie rzeczywiście mogło być tajne. $\mathrm{Z}$ tego opisu wynika, że wyborcy byli uprawnieni do oddania tylu głosów, ile mandatów było do obsadzenia, a więc w Koronie miał być stosowany system głosowania blokowego. Posłami mieli zostać kandydaci z kolejno największym poparciem. W przypadku remisu, „dziecię” miało gałkami wylosować zwycięskiego kandydata. Cała procedura miała być monitorowana przez kandydatów do mandatu poselskiego. Kombinowanym sposobem miała być także przyjmowana instrukcja dla posłów [Volumina Legum, 1952, t. X: 119-123, 127-133. Opisana procedura wyborcza nawiązywała do rozwiązań przyjętych przez sejm obradujący na przełomie 1767/1768 roku.

Z kolei na sejmikach litewskich, jeżeli nie doszło do jednozgodnego wyboru posłów, tajne głosowanie większościowe miało być przeprowadzane według regulacji z 1791 roku, a więc z wykorzystaniem gałek, wrzucanych do dwukomorowego „wazonu”. Wypływa stąd wniosek, że w Wielkim Księstwie Litewskim - z punktu widzenia uprawnień wyborcy - nadal stosowany miał być system głosowania aprobującego. W przypadku remisu -odmiennie niż w Koronie - na Litwie o obsadzeniu mandatu poselskiego miało rozstrzygać sprawowanie urzędu. Kombinacja zasad jednozgodności i większości miała obowiązywać także do przyjmowania instrukcji poselskiej. W tym punkcie regulacje dla Korony i Litwy także się różniły. Jeżeli bowiem w Koronie nie udało się przyjąć 
instrukcji jednozgodnie, to przyjmowano w większościowo poszczególne jej punkty - poprzez rozchodzenie się stron na „tak” lub „nie” i zliczanie zajętych stanowisk. Natomiast na Litwie, w przypadku braku zgody, poszczególne punkty miały być przyjmowane poprzez tajne głosowanie większościowe, przeprowadzane za pomocą gałek wrzucanych do ,wazonu” [Volumina Legum, 1952, t. X: 125, 130-133]. Wskazane różnice w procedurach postępowania sejmików obu prowincji państwa polskiego raczej nie były przypadkowe. Autorzy Praw kardynalnych wprowadzili je świadomie, by w ten sposób podkreślić odrębność Korony i Wielkiego Księstwa Litewskiego.

\section{PODSUMOWANIE}

Wchodząc $\mathrm{w}$ dobę parlamentaryzmu Polska przedrozbiorowa nie przyjęła jednolitych zasad wybierania izby poselskiej. Jednak w miarę utrwalania się obecności sejmu jako kluczowego organu decyzyjnego, praktyka powoływania posłów w XVI i XVII wieku ewolucyjnie formowała wyraźny wzór systemu wyborczego. W zmodyfikowanej postaci znalazł zastosowanie w planach reformowania ustroju politycznego Rzeczypospolitej, a zwłaszcza w reformie państwa dokonanej przez Sejm Czteroletni. W kilku ustawach towarzyszących Konstytucji 3 maja z 1791 roku przyjęto jednolity system wyborczy do izby poselskiej. Zasadniczo utrzymały się w nim lub też były rozwijane kluczowe elementy wzoru wcześniej wykształconego.

W nawiązaniu do owego wzoru, terytorialną podstawą wyboru posłów uczyniono małe jednostki terytorialne, a ściśle - sejmiki ziem i powiatów. O ile do końca XVII wieku spośród 69 sejmików poselskich, aż 19 były to sejmiki wojewódzkie, tak w systemie wyborczym z 1791 roku już tylko w pięciu przypadkach (na 102) elekcja posłów miała nastąpić na sejmikach wojewódzkich. We wzorze widoczna była skłonność do wyłaniania posłów w małych okręgach wyborczych, liczących od dwóch do ośmiu mandatów, z widoczną jednak przewaga okręgów dwumandatowych. System wyborczy z 1791 roku uwzględnił tę tendencję i wprost wprowadził system binominalny, modyfikacja wzoru polegała na wprowadzeniu sieci 102 okręgów dwumandatowych. W rozwiązaniach z 1791 roku generalnie podtrzymano też wynikający z wzoru koncept oparcia wyborów na kombinacji zasady jednozgodności i zasady większości, z zastosowaniem większości względnej. W przypadku potrzeby odwołania się trybu większościowego wystąpiła jednak znacząca, podwójna różnica pomiędzy wzorem wypracowanym do końca XVII wieku, a rozstrzygnięciami z 1791 roku. Po pierwsze, we wzorze większość zwykła miała być otrzymywana na ogół w głosowaniu jawnym i potwierdzona odpowiednią liczbą kresek stawianych przy nazwiskach kandydatów. System wyborczy z 1791 roku, 
w przypadku odwołania się do formuły większościowej, wprowadził wybory tajne. Po drugie, ta modyfikacja wzoru pociągnęła za sobą zmianę uprawnień wyborcy. W myśl procedury wyborczej istniejącej we wzorze, szlachcic - wyborca mógł oddać tyle głosów, ile mandatów poselskich było do obsadzenia, a więc wybierał w systemie głosowania blokowego. Natomiast w świetle regulacji z 1791 roku szlachcic wyborca oddawał głos poprzez wrzucenie gałki do jednej z dwóch komór urny wyborczej; wielokrotnie podchodząc do głosowania, teoretycznie mógł za każdym razem akceptować każdego z kandydujących. We wzorze zachowywał się on zgodnie z logika głosowania blokowego, oddawał tyle głosów, ile mandatów było do obsadzenia. Natomiast w rozwiązaniach z 1791 roku zastosowano głosowanie aprobujące. Intencja jego świadomego przyjęcia nie jest klarowna, ale nie zmienia to faktu, że w myśl przyjętej procedury wybierania posłów, szlachcic wyborca mógł w każdym przypadku wrzucić gałkę do komory akceptującej kandydata. Przyjęty w 1791 roku system wyborczy został skorygowany przez sejm grodzieński w roku 1793.

\section{BIBLIOGRAFIA}

Bardach Juliusz, Grodziski Stanisław, Gwiżdż Andrzej, Jankiewicz Adam, Działocha Kazimierz, Kraczkowski Romuald. 1993. Dzieje Sejmu Polskiego. Warszawa: Wydawnictwo Sejmowe.

Choińska-Mika Jolanta. 1998. Sejmiki mazowieckie w dobie Wazów. Warszawa: Wydawnictwo Sejmowe.

Czapliński Władysław. 1957. Dawne czasy. Wrocław: Ossolineum.

Dyaryusz sejmiku proszowskiego przedsejmowego roku 1584. 1912. Nadbitka z Przegladu Historycznego 15.

Dzięgielewski Jan. 1993. Stan szlachecki.... W Anna Sucheni-Grabowska, Alicja Dybkowska (red.), Tradycje polityczne dawnej Polski. Warszawa: Editions Spotkania.

Hoffman Karol Boromeusz. 1988. Historia reform politycznych w dawnej Polsce. Warszawa: Państwowy Instytut Wydawniczy.

Historia państwa i prawa Polski. Źródła. 1997. Wyboru dokonali Franciszek Połomski, Piotr Jurek. Wrocław: Wrocławskie Zakłady Graficzne.

Michalski Jerzy (red.). 1984. Historia sejmu polskiego. T. I, Do schytku szlacheckiej Rzeczypospolitej. Warszawa: Państwowe Wydawnictwo Naukowe.

Kriegseisen Wojciech. 1991. Sejmiki Rzeczypospolitej szlacheckiej w XVII i XVIII wieku. Warszawa: Wydawnictwo Sejmowe .

Leśnodorski Bogusław. 1947. Parlamentaryzm w Polsce. Kraków: Wydawnictwo M. Kot.

Miasta nasze królewskie wolne w państwach Rzeczypospolitej. 1997. W Historia państwa i prawa Polski. Źródła. Wyboru dokonali Franciszek Połomski, Piotr Jurek, Wrocław: Wrocławskie Zakłady Graficzne.

Olszewski Henryk. 1966. Sejm Rzeczypospolitej epoki oligarchii 1652-1763. Prawo-praktyka - teoria - programy. Poznań: Uniwersytet im. Adama Mickiewicza w Poznaniu.

Olszewski Henryk. 2002. Sejm w dawnej Rzeczypospolitej. Ustrój i idee. T. 2. Studia i rozprawy. Poznań: Uniwersytet im. Adama Mickiewicza w Poznaniu, . 
Pawiński Adolf. 1978. Rządy sejmikowe w Polsce 1572-1795 na tle stosunków województw kujawskich. Warszawa: Państwowy Instytut Wydawniczy.

Płaza Stanisław. 1987. Sejmiki i zjazdy szlacheckie województwa sieradzkiego. Ustrój i funkcjonowanie (1572-1632). Cz. I. Warszawa-Kraków: Państwowe Wydawnictwo Naukowe .

Prochaska Antoni. 1898. Geneza i rozwój parlamentaryzmu za pierwszych Jagiellonów. Kraków: Akademia Umiejętności .

Rzążewski Kazimierz, Słomczyński Wojciech, Życzkowski Karol. 2014. Każdy głos się liczy! Wędrówka przez krainę wyborów. Warszawa: Wydawnictwo Sejmowe. Siemieński Józef. 1906. „Organizacja sejmiku ziemi dobrzyńskiej”. Rozprawy i Sprawozdania z Posiedzeń Wydzialu Historyczno-Filozoficznego Akademii Umiejętności w Krakowie” 23.

Sokala Andrzej, Michalak Bartłomiej, Uziębło Piotr. 2013. Leksykon prawa wyborczego i referendalnego oraz systemów wyborczych. Warszawa: Wolters Kluwer SA.

Śreniowski Stanisław. 1938. Organizacja sejmiku halickiego. Lwów: Towarzystwo Naukowe.

Sucheni-Grabowska Anna, Dybkowska Alicja (red.). 1993. Tradycje polityczne dawnej Polski. Warszawa: Editions Spotkania.

Włodarczyk Jerzy. 1973. Sejmiki łęczyckie. Łódź: Wydawnictwo Uniwersytetu Łódzkiego.

Volumina Legum. 1860. T. VII. Petersburg: Wyd. Josefat Ohryzko.

Volumina Legum. 1889. T. IX. Kraków: Wydawnictwo Komisji Prawniczej Akademii Umiejętności w Krakowie.

Volumina Legum. 1952. T. X. Poznań: Poznańskie Towarzystwo Przyjaciół Nauk.

www.wilanow-palac.pl/jak_wybierano_poslow_na_sejm_glosowanie_na_sejmiku_przedsejmowym_w_proszowicach_w_1689_r.html.

\section{STRESZCZENIE}

W artykule omówiono tworzenie systemu wyborczego starej Polski. Proces ten ewolucyjnie wytworzył wzór wybierania posłów na sejm. Obejmował dążenie do wybierania posłów w małych jednostkach terytorialnych, na podstawie kombinacji wyborów jednomyślnych i większościowych, w systemie głosowania blokowego. Omówiono implementację tego wzoru w systemie wyborczym przyjmowanym w ramach reformowania Polski w końcu XVIII wieku.

Słowa kluczowe: demokracja, głosowanie blokowe, głosowanie aprobujące, izba poselska, poseł, szlachta, sejmik.

\section{POLISH ELECTION SYSTEM PATTERN OF PRE-PARTITION PERIOD (XV-XVIII CENTURIES) (summary)}

The article presents the formation of the election system of old Poland. The process created, in evolutional way, the pattern of electing members of the Diet. It involved aiming at electing deputies in small territorial units based on combination of unanimous and majority votes, in the system of block vote. The article discusses the implementation of this pattern in the voting system established within reformation of Poland at the end of XVIII century.

Keywords: democracy, block vote, approving vote, chamber of deputies, deputy, nobility, council. 